\title{
Impact of wind speed and apartment ventilation on indoor concentrations of PM10 and PM2.5 in Kraków, Poland
}

\author{
Monika Ścibor $^{1}$ (D) - Anita Bokwa ${ }^{2}$ (D) - Bartosz Balcerzak ${ }^{1}$ (D) \\ Received: 3 December 2019 / Accepted: 16 March 2020 / Published online: 31 March 2020 \\ (C) The Author(s) 2020
}

\begin{abstract}
In the period 2013-2015, $\mathrm{PM}_{2.5}$ and $\mathrm{PM}_{10}$ outdoor and indoor concentrations were measured on 23 days in cold half-year periods, in Kraków, Poland. Air pollution is still a serious health hazard for the inhabitants as Kraków is located in a concave landform and smog episodes occur often in the city during the heating periods, due to poor natural ventilation and frequent air temperature inversions. The $\mathrm{PM}_{10}$ and $\mathrm{PM}_{2.5}$ concentrations were studied for very good and very poor weather conditions concerning air pollution. Each subgroup was further divided into cases when the apartments' windows were kept open or closed. Daily courses of $\mathrm{PM}_{10}$ and $\mathrm{PM}_{2.5}$ concentrations were very dynamic. Weather pattern, in particular wind speed and atmospheric stability, largely determined the concentrations of $\mathrm{PM}_{10}$ in ambient air. The share of $\mathrm{PM}_{2.5}$ in $\mathrm{PM}_{10}$ indoor concentrations reached around $70 \%$ for both types of weather conditions. The share of indoor $\mathrm{PM}_{10}$ and $\mathrm{PM}_{2.5}$ mean concentrations in the outdoor values was higher during good than during poor weather conditions by about $10 \%$.
\end{abstract}

Keywords Particulate matter · Outdoor dispersion · Ventilation · Environmental health hazard · Urban areas · Heating season

\section{Introduction}

Particles $\mathrm{PM}_{2.5}$ and $\mathrm{PM}_{10}$ are primary factors of adverse health effects from air pollution (e.g., Wallace 2000; Pope and Dockery 2006; World Health Organization 2013; Taneepanichskul et al. 2018; Paoin et al. 2020). As the urban population increases and the cities' inhabitants spend more and more time indoors (e.g., Wallace 1996; Almeida-Silva et al. 2014), the exposure to indoor air pollution (such as, $\mathrm{PM}_{2.5}$ and $\mathrm{PM}_{10}$ ) becomes an important health risk (e.g., Blondeau et al. 2005; Ścibor et al. 2019a). Due to the lesser degree of dilution, chemical transformation, and dispersion, as well as higher number of occupants indoors, exposures per

Electronic supplementary material The online version of this article (https://doi.org/10.1007/s11869-020-00816-8) contains supplementary material, which is available to authorized users.

Anita Bokwa

anita.bokwa@uj.edu.pl

1 Department of Environmental Health, Faculty of Health Sciences, Jagiellonian University Medical College, Kraków, Poland

2 Faculty of Geography and Geology, Institute of Geography and Spatial Management, Jagiellonian University, 7 Gronostajowa St., 30-387 Kraków, Poland unit mass of $\mathrm{PM}_{2.5}$ emitted indoors are two to three orders of magnitude larger than exposures to emissions to the outdoor environment (e.g., Klepeis and Nazaroff 2006; Ilacqua et al. 2007). Ratios between contaminant concentrations indoors and outdoors were the subject of numerous studies (e.g., Morawska et al. 2001; Blondeau et al. 2005; Cao et al. 2005), as infiltration of outdoor pollutants is one of the sources of indoor air pollution (e.g., Chen and Zhao 2011). For example, Shi et al. (2017) showed that the migration of outdoor $\mathrm{PM}_{2.5}$ is influenced by differences in building envelope, ventilation, and particle size distribution. MacNeill et al. (2014) found out that there is a significant amount of variability in the infiltration factor and the ambient/non-ambient components of indoor fine particles; regional factors such as climate, housing stock, air-conditioning use, and window opening influence the contribution of ambient particles upon indoor residential concentrations.

Weather conditions are considered mainly as a factor contributing to ambient air quality, due to their role in the dispersion, transformation, and removal of atmospheric pollutants from the atmosphere (e.g., Li et al. 2015; Deng et al. 2019). In urban environments, severe pollution episodes result primarily from unfavorable weather conditions (Seinfeld and Pandis 1998; Prtenjak et al. 2009; Toro et al. 2019). Precipitation has a great impact on concentrations of particulate matter and it mainly washes out coarse particles while have little effect on 
fine particles (Li et al. 2015). However, atmospheric conditions are also important for indoor air pollution level. For example, Klaić et al. (2015) investigated the relationship between wintertime 1-min mean urban indoor PM1 mass concentrations and outdoor atmospheric conditions and showed a decrease in PM1 with an increase in concurrent outdoor temperature, precipitation amount, and horizontal wind velocity, while PM1 increased with outdoor relative humidity.

The aim of the paper is to show the impact of ambient weather conditions, and wind speed in particular, on indoor air pollution with $\mathrm{PM}_{10}$ and $\mathrm{PM}_{2.5}$ during the cold half-year (Oct.-Mar.) in the city of Kraków, Poland. Kraków is one of the most polluted cities in Europe concerning $\mathrm{PM}_{10}$ and $\mathrm{PM}_{2.5}$ as it belongs to $6 \%$ of all European measurement sites where the mean annual limit value of PM10 (i.e., $40 \mu \mathrm{g} \mathrm{m}^{-3}$ ) and 5\% of sites where the mean annual limit value of PM2.5 (i.e., $25 \mu \mathrm{g} \mathrm{m}^{-3}$ ) were exceeded in 2016 (European Environment Agency 2018). That means that the inhabitants' exposure to PM from outdoor sources may also be among the highest in Europe. In 2018, mean annual $\mathrm{PM}_{10}$ concentrations in Kraków varied from 33 (eastern suburbs) to $57 \mu \mathrm{g} \mathrm{m}^{-3}$ (city center) and in case of $\mathrm{PM}_{2.5}$ it was $29 \mu \mathrm{g} \mathrm{m}^{-3}$ in southern suburbs (no average values of $\mathrm{PM}_{2.5}$ were available for other points) (Inspectorate of Environmental Protection 2019). High air pollution is mainly connected with a specific combination of natural conditions (described in the "Study area" section) which significantly decrease natural ventilation of the city and gain a particular importance in the cold half-year, during the heating season. Ambient air pollution in Kraków was a subject of numerous studies (e.g., Niedźwiedź and Olecki 1995; Bokwa 2008; Hajto and Rozwoda 2010; Ścibor et al. 2019b) and a strong dependence of high PM concentrations on weather conditions was shown (e.g., Lewińska et al. 1982; Niedźwiedź and Olecki 1994; Walczewski et al. 2000; Bokwa 2011). However, little is known about the impact of weather conditions on indoor PM concentrations in Kraków, including the impact of the specific local environmental features. As mentioned above, indoor concentrations depend on outdoor conditions in many ways. What matters is the outdoor concentration of air pollution because the higher it is, the more pollution can migrate indoors. The migration conditions depend not only on building characteristics but also on, e.g., wind speed, precipitation, or air temperature as those parameters have an impact on physical processes linked to ventilation. Therefore, it is assumed in the present study that during the heating season in Kraków, when PM is delivered to the ambient air continuously and weather conditions are the main reason for large changes in PM concentrations, the indoor concentrations are also dependent on those weather conditions, mainly on the wind speed. The results obtained should support the mitigation strategies promoted by the city authorities and recommended to the inhabitants. Additionally, the conclusions may also apply to the air pollution situation in other cities located in concave land forms and with poor natural ventilation.

\section{Study area}

Kraków is located in southern Poland, on the Wisła River, at the junction of three regions: the Carpathian Mts., Polish Uplands, and the chains of basins located in between, running along the Carpathian chain. Therefore, the environmental conditions of the city and its vicinities are largely diversified. The city has an area of $326.8 \mathrm{~km}^{2}$ and the number of inhabitants reaching 765 thousand (data of Dec. 2016; Statistical Yearbook of Kraków 2017). The city's central part, with the Wisła river valley, is located at an altitude of about $200 \mathrm{~m}$ a.s.l. In the western part, the valley is as narrow as $1 \mathrm{~km}$ as it is enclosed by hills reaching over $100 \mathrm{~m}$ above the valley floor. However, in the eastern part of the city, the valley widens to about $10 \mathrm{~km}$ and there is a system of river terraces. The hilltops bordering the city to the north and the south reach about $100 \mathrm{~m}$ above the river valley floor, similar to the hilltops in the valley which means that the city is located in a concave land form (open only to the east), and sheltered from the prevailing western winds (Fig. 1). The local climate processes linked to the impact of relief include, for example, katabatic flows, cold air reservoir formation, frequent air temperature inversions, and much lower wind speed in the valley floor than at the hilltops. Those factors contribute largely to the abundant air pollution (e.g., Walczewski et al. 2000).

Local emissions of PM are mainly linked to industry, traffic, and domestic heating. Even though $90 \%$ of apartments in Kraków belong to the central heating system (i.e., mainly two large power plants operated by burning coal; Statistical Yearbook of Kraków 2019), domestic heating (furnaces or stoves) is a significant source of PM particularly during the cold half-year which often contributes to smog situations. During the time when the measurements were taken, individual heating systems used to operate on coal and wood. However, high smog events frequency cannot be explained with emission volume only. The abundant air pollution in Kraków is the effect of a combination of local and distant emissions, and local environmental conditions which generate local climate processes like air temperature inversions or katabatic flows, described above. Due to such processes, even relatively small emissions can lead to very high concentrations of air pollutants as the dispersion conditions are very unfavorable. High mean annual concentrations are generated mainly during the cold half-year, i.e., during the heating season. According to Hajto and Rozwoda (2010), who studied sodar data from Kraków with hourly resolution, in the months from October to March, the mean monthly frequency of stable atmosphere conditions varies from $58.1 \%$ in March to $74.0 \%$ in 
Fig. 1 Location of measurement sites. Explanations:

meteorological measurement sites: 1-Balice, 2-Botanical Garden, 3-TV mast, 4Jeziorzany, 5-Libertów; PM measurement sites: small red dots show the location of apartments; some dots represent a few apartments located close to each other

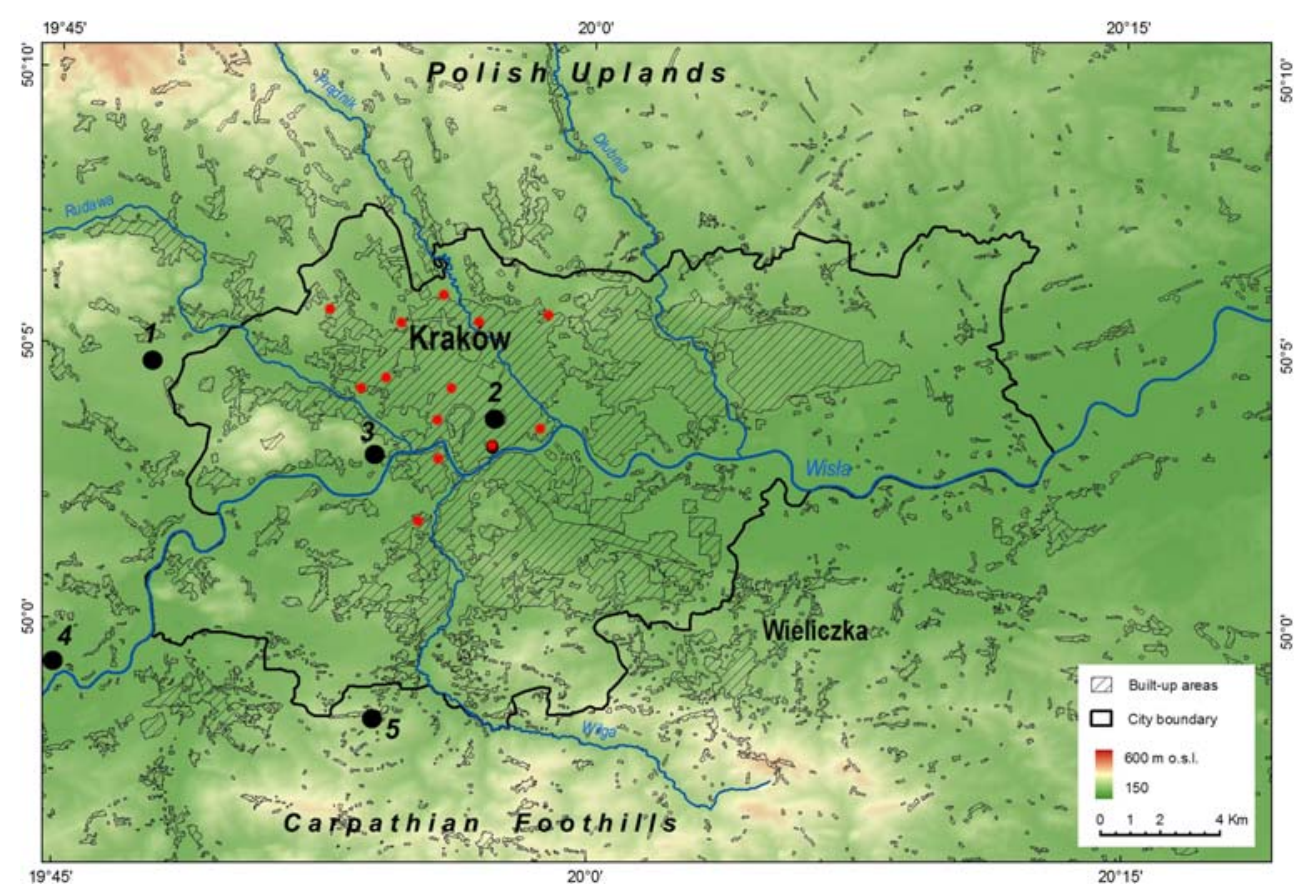

December, and during stable atmospheric conditions, $\mathrm{PM}_{10}$ concentrations increase and are the highest.

\section{Data and methods}

The measurements of outdoor and indoor PM concentrations have been conducted in Krakow during the period between March 2013 and September 2015, for 179 days and in 168 apartments (in 11 cases the measurement were conducted during two consecutive days in the same apartment), within the project mentioned in the acknowledgements. In order to apply the data in the present study on the impact of weather conditions on indoor PM concentrations, only data from the cold half-year periods (Oct. 2013 - Mar. 2014 and Oct. 2014Mar. 2015) were included as the PM concentrations exceed the allowed values in Kraków mainly during that part of the year. In the cold half-years, there were 98 days with measurements available, conducted in 91 apartments. All apartments were of comparable standard, i.e., they were located in a multi-storey blocks of flats, linked to the municipal central heating system (i.e., there was no local heating installation nearby which could influence the measurements by intensive emissions), and were equipped with gravitational ventilation only (i.e., no mechanical ventilation devices were used in the buildings). As cooking appliances can be an important source of particulate matter (Isaxon et al. 2015), we have made sure that our measuring devices were not placed in kitchens. All apartments selected for analysis were equipped with gas cookers only, and they were used very rarely. The publication by Ścibor et al. (2019b) showed that this factor did not have a statistically significant effect on the $\mathrm{PM}_{10}$ and $\mathrm{PM}_{2.5}$ indoor concentration during the measurement campaign. None of the inhabitants declared smoking cigarettes. Therefore, it was assumed that the indoor sources of PM are comparable for all the cases, concerning the apartments' standards and habits of the inhabitants. The apartments were located on various floors of the buildings, from the ground floor to the 5th floor, and only in one case the 10th floor. However, as shown by Gemenetzis et al. (2006) in the study conducted in university rooms in Greece, although a slight decrease in $\mathrm{PM}_{10}$ and $\mathrm{PM}_{2.5}$ mass concentrations was observed with an increase in the elevation level, it could be considered as negligibly small up to the 5 th floor. The effect of elevation (up to the 40th floor) on indoor particulate concentrations was also studied by Chao and Wong (2002), who reports no significant difference in the $\mathrm{PM}_{10}$ and $\mathrm{PM}_{2.5}$ mass concentrations at different levels.

Measurements of $\mathrm{PM}_{10}$ and $\mathrm{PM}_{2.5}$ were realized using SidePak AM510 personal aerosol monitors. The device uses light scattering photometric technology to determine aerosol mass concentrations in real-time (more details at: https://www. tsi.com/home/). In accordance with the device manufacturer's recommendations, the devices were first calibrated. The performance of SidePak monitors was compared with gravimeter samplers, used as reference devices by the Voivodship Inspectorate for Environmental Protection in Krakow, in the form of 24-h co-measurements. The devices underwent calibration every 2 weeks during the measurement period. In order to protect the outdoor measurement devices from weather conditions, special boxes made of styrofoam were used. Their design was consulted with the device's manufacturer in order to prevent any measurement errors. 
Additionally, simultaneous trial measurements for devices with and without the boxes were conducted and no significant differences in the results were found.

Two devices were placed inside an apartment, from which one registered $\mathrm{PM}_{10}$ and the other $\mathrm{PM}_{2.5}$. At the same time, two other devices were placed outside (on a window sill or balcony), registering $\mathrm{PM}_{10}$ and $\mathrm{PM}_{2.5}$. The measurements were started at 00:01 a.m. and finished at 23:59 p.m. The devices recorded the 15-min average concentrations of PM. For each locality, a participant was asked to fill out a questionnaire concerning housing conditions. The locations of PM measurement sites are presented in Fig. 1.

In order to verify the hypothesis that weather type has a meaningful impact on indoor air pollution, two types of weather conditions were defined: very good and very poor ones for efficient air pollution dispersion. The weather conditions were defined first of all with the wind speed as it largely determines air pollution dispersion conditions. The anemological data used come from a rural meteorological station located west of Krakow, in the airport of Balice, operated by the Institute of Meteorology and Water ManagementNational Research Institute, and from an urban meteorological station located in the city center, in the Botanical Garden, operated by the Jagiellonian University, Institute of Geography and Spatial Management (Fig. 1). Wind speed was measured there at 6,12 , and 18 UTC. The comparison of the values recorded at both stations shows the impact of urban build-up on the significant decrease of that element which largely deteriorates aerosanitary conditions inside the city area (e.g., Yang et al. 2020). Additionally, each day with PM measurements was characterized with a few elements. Daily precipitation sums and time of precipitation occurrence (data from the urban station) were included as it strongly affects the ambient PM concentrations (e.g., Li et al. 2015). Hourly cloudiness amount and type (data from the rural station) determines the amount of solar radiation reaching the ground during the day but it also decreases the amount of longwave radiation lost by the ground which in turn is closely connected with the conditions for air temperature inversion formation (Oke 1987). Air temperature gradient in the vertical profile of the Vistula valley in Kraków was obtained from the continuous ground measurements performed with the temporal resolution of $5 \mathrm{~min}$ in two rural points: Jeziorzany (river valley bottom) and Libertów (a hill top nearby) and from the measurements at the TV mast (Fig. 1). In both cases, the height difference between the measurement points is close to $100 \mathrm{~m}$. The measurement points are operated by the Jagiellonian University, Institute of Geography and Spatial Management (Bokwa 2010). Stable atmosphere conditions, including the air temperature inversion, is a factor significantly decreasing the natural dispersion conditions as convective air movements are blocked and air pollution is kept close to the ground, e.g., under the inversion layer (Oke 1987). Stable atmosphere and the occurrence of air temperature inversions were defined as the vertical temperature gradient $<0.9 \mathrm{~K}$ $100 \mathrm{~m}$, and it was determined using the measurements from Jeziorzany and Libertów. Those measurements were verified with the measurements from the TV mast, which were not used for the calculations due to missing data for some of the days analyzed. Synoptic situation type was defined according to the classification of T. Niedźwiedź for southern Poland (Niedźwiedź 2019). Additionally, the days analyzed were divided into cases where in the apartments the windows were kept open or closed during the measurements, as a number of studies have shown higher indoor levels associated with greater apartment ventilation (Clayton et al. 1993; Rojas-Bracho et al. 2000; Williams et al. 2003). The duration of window openings was not assigned to the apartments in advance as it was strongly dependent on personal preferences and current weather conditions.

Very poor weather conditions for air pollution dispersion were assigned to days with wind speed in all three measurement terms no higher than $2 \mathrm{~m} \mathrm{~s}^{-1}$ at the rural station, while very good conditions were assigned to days with wind speed in all three measurement terms of at least $3 \mathrm{~m} \mathrm{~s}^{-1}$ in the rural station. The measurements at the urban station are affected by the presence of urban build-up, and the wind speed values are always lower than in the rural station. Therefore, only the values from the rural station were considered as representative in the local scale. The value of $2 \mathrm{~m} \mathrm{~s}^{-1}$ was applied following the results of Vecchi et al. (2004), who noticed a typical increase by $20-35 \%$ in both $\mathrm{PM}_{1}$ and $\mathrm{PM}_{2.5}$ on days when wind velocity was lower than $2 \mathrm{~m} \mathrm{~s}^{-1}$.

From 98 days with PM measurements, 23 days were chosen which fulfilled the criteria, 11 days with very good weather conditions (i.e., with high wind speed) and 12 days with very poor conditions (i.e., low wind speed). The number of days analyzed seems to be sufficient for drawing the conclusions, as many studies on indoor air pollution are realized with short-term measurements, e.g., Pekey et al. (2010) used measurements from 30 days selected from a 2-month measurement campaign, MacNeill et al. (2014) based their study on measurements from seven consecutive days in both summer and winter, Hu et al. (2019) conducted the measurements in three 2-week periods, Cao et al. (2005) measured indoor and outdoor concentrations in three localities and each of them for 3 days, and Blondeau et al. (2005) carried out the measurements for two 2-week periods in each of 8 localities, one during winter and the other during spring or summer. Additionally, the chosen days present only extreme, border conditions, i.e., either very good or very poor weather conditions, so as to show the differences in the impact on indoor concentrations clearly.

The PM measurements were divided into data sub-series, following the criteria of weather conditions and window opening option. The series were used to calculate the indoor/ 
outdoor ratio (I/O), and the ratios of PM2.5/PM10. For each series, mean values and the variability coefficient (in \%) were calculated. The coefficient was defined as: $x=(d / m) \cdot 100$, where: $d$ is standard deviation, and $m$ is mean value; results exceeding $20 \%$ were considered to show high variability. Indoor/outdoor ratios were analyzed with regression analysis following the pattern proposed by Hänninen et al. (2011), separately for days with good and poor weather conditions and for cases with windows kept opened or closed. The data series were the subject of the analysis with $t$ test and the differences were considered statistically significant at $p<0.01$.

\section{Results}

Figure 2 shows mean outdoor and indoor PM concentrations for both groups of days with good and poor weather conditions for air pollution dispersion. Both indoor and outdoor PM concentrations differ a lot. On days with poor weather conditions, the outdoor concentrations are three to four times larger than during good conditions. The differences reach 23.1 and $39.7 \mu \mathrm{g} \mathrm{m}^{-3}$ for indoor values, and 58.6 and $106.7 \mu \mathrm{g} \mathrm{m}^{-3}$ for outdoor values (in both cases: for $\mathrm{PM}_{2.5}$ and $\mathrm{PM}_{10}$, respectively). The $t$ test showed that the differences are statistically significant.

In the case of $\mathrm{PM}_{10}$, the allowed outdoor mean daily value of $50 \mu \mathrm{g} \mathrm{m}^{-3}$ was slightly exceeded only on 3 days during good weather conditions, while during poor conditions the limit was largely exceeded on all days. However, for indoor

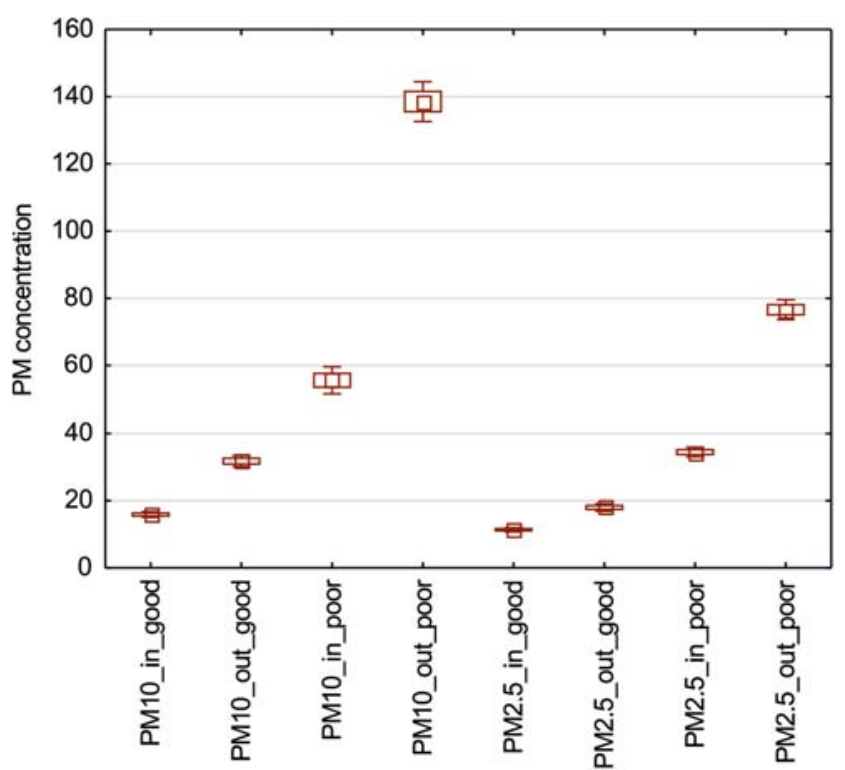

Fig. 2 Mean outdoor and indoor concentrations of $\mathrm{PM}_{10}$ and $\mathrm{PM}_{2.5}$ (in $\mu \mathrm{g} \mathrm{m}^{-3}$ ) during good and poor weather conditions for air pollution dispersion. Explanations: box - standard error of the mean, whiskers95\% confidence interval values, the limit was not exceeded during good weather conditions and during the opposite conditions there were only 4 cases with mean daily concentrations above $50 \mathrm{\mu g} \mathrm{m}^{-3}$. That shows the dominating role of the weather pattern, in particular wind speed and atmospheric stability, in controlling the concentrations of $\mathrm{PM}_{10}$ in ambient air in Kraków. In the case of $\mathrm{PM}_{2.5}$, the daily WHO air quality limit guideline of $25 \mu \mathrm{g} \mathrm{m}^{-3}$ can be considered as an allowed threshold (Hu et al. 2019), because in Polish legislation there is no mean daily $\mathrm{PM}_{2.5}$ concentration limit accepted. For outdoor concentrations, the allowed mean daily value of $25 \mathrm{\mu g} \mathrm{m}^{-3}$ was exceeded only on 2 days during good weather conditions, while during poor conditions the limit was largely exceeded on all days. For indoor values, the threshold was not exceeded on all days with good weather conditions and only on 4 days with poor conditions. That means that air pollution with $\mathrm{PM}_{2.5}$ is a much more severe problem in Kraków concerning indoor air quality during poor weather conditions than $\mathrm{PM}_{10}$, while for outdoor air pollution the situation is the same for both fractions.

Online Resources 1 and 2 show basic statistics for the data series divided further in relation to the window opening. Online Resource 3 presents the values of basic weather elements for all days analyzed in order, on the one hand, to show differences in meteorological conditions in both groups of days, but on the other hand, to present their large diversity. Data series presented in Online Resource 2 were analyzed with $t$ test which revealed that window opening makes statistically significant difference in case of mean concentrations of $\mathrm{PM}_{10}$, in both types of weather conditions, but in the case of $\mathrm{PM}_{2.5}$, the differences are not significant, regardless weather type.

Figure 3 shows the share of $\mathrm{PM}_{2.5}$ in $\mathrm{PM}_{10}$ concentrations for the particular data series. The indoor and outdoor series were analyzed with $t$ test separately. Values for poor weather conditions are significantly higher than for good weather conditions. For indoor series, it showed no statistically significant differences between the mean values obtained when windows were kept open or closed, regardless the weather conditions. For outdoor conditions, the mean values (39.7 to $63.9 \%$ ) are clearly smaller than for indoor conditions (70.4 to $83 \%$ ). Those values show again that the indoor air pollution with $\mathrm{PM}_{2.5}$ is more severe than the outdoor one as a larger share of $\mathrm{PM}_{2.5}$ fraction means a higher risk of lung cancer and other lung diseases. The share of $\mathrm{PM}_{2.5}$ in $\mathrm{PM}_{10}$ found in Kraków is similar, e.g., to the results obtained for various indoor locations in Belgium: on average 73\% (Buczyńska et al. 2014).

The indoor/outdoor ratio ( $\mathrm{I} / \mathrm{O})$ of air pollution is an indicator of whether indoor levels are influenced by significant indoor sources of particulates or if indoor levels are the result of outdoor particle concentrations (Pekey et al. 2010). Cao et al. (2005) noted that high I/O ratios can be caused by: (1) elevated indoor concentrations, (2) low outdoor concentrations, or (3) some combination of these two factors. Figure 4 shows I/O ratios for the particular data series. 


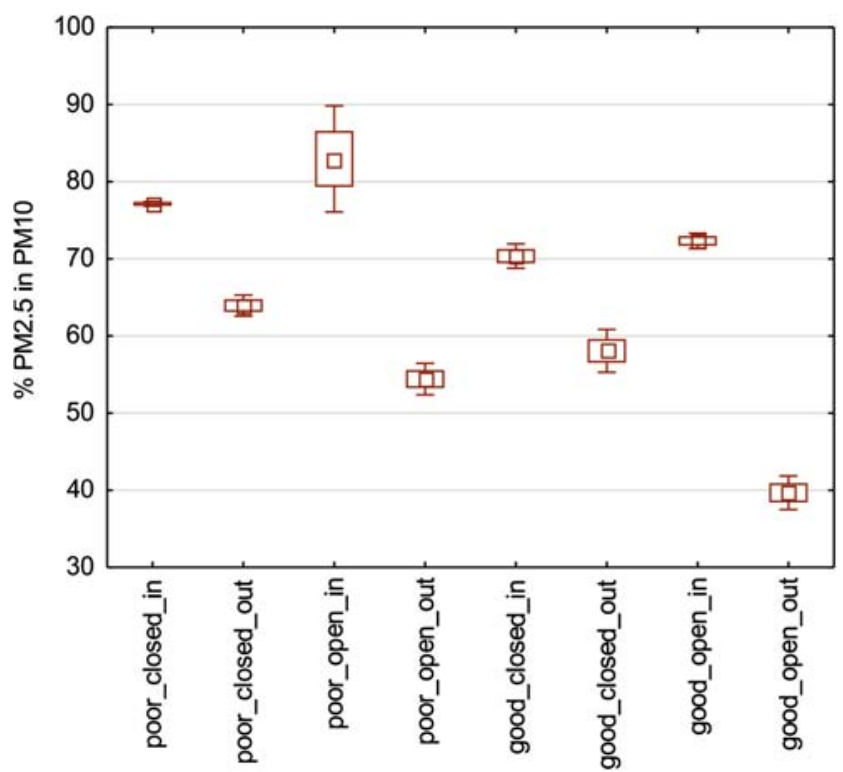

Fig. 3 Mean share (\%) of $\mathrm{PM}_{2.5}$ in $\mathrm{PM}_{10}$ concentrations for particular data series. Explanations: box - standard error of the mean, whiskers95\% confidence interval

Indoor concentrations were much lower than outdoor ones in most cases. Very high $\mathrm{I} / \mathrm{O}$ values for $\mathrm{PM}_{2.5}$ at good weather conditions are due to data concerning 3 days (20, 22, and 24 Dec., 2014) when indoor $\mathrm{PM}_{2.5}$ concentrations were 2 to 4 times higher than the outdoor ones. Those were the days with the highest wind speed from all days analyzed (Online Resource 3) and the mean concentrations of $\mathrm{PM}_{2.5}$ were the lowest. Therefore, relatively small differences in absolute values turned out to generate such high percentage numbers. Removal of the data concerning the 3 days mentioned lowers

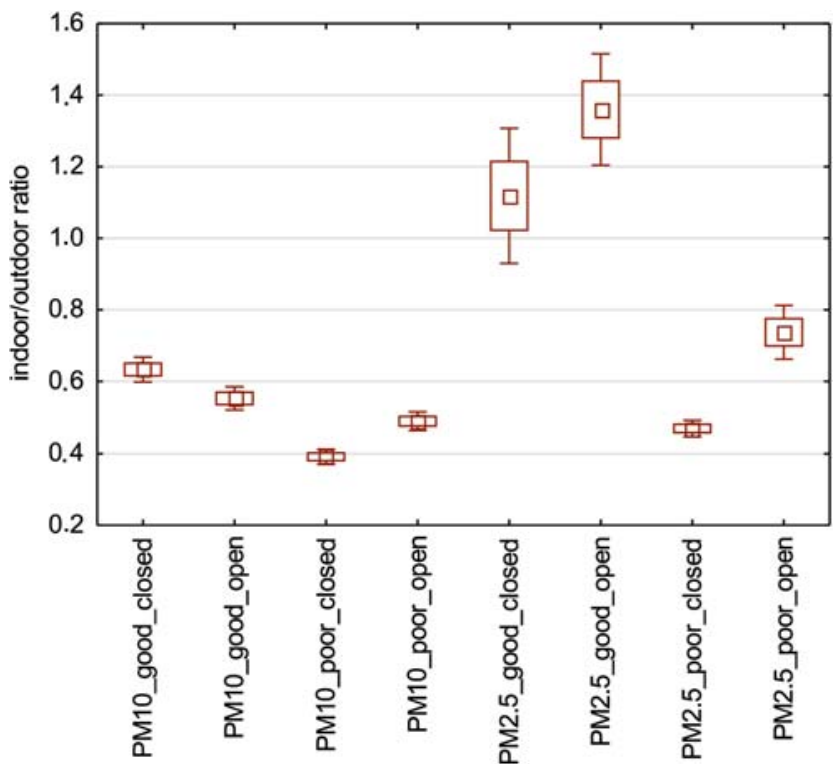

Fig. 4 Indoor/outdoor ratio (I/O) of $\mathrm{PM}_{10}$ and $\mathrm{PM}_{2.5}$ for particular data series. Explanations: box — standard error of the mean, whiskers-95\% confidence interval the highest value to the level of 0.6 while the other one remains 1.3. The $t$ test showed that weather conditions and window opening are factors with a statistically significant impact on $\mathrm{I} / \mathrm{O}$. Mean $\mathrm{I} / \mathrm{O}$ values for $\mathrm{PM}_{10}$ and $\mathrm{PM}_{2.5}$ are higher when windows are closed during poor weather conditions. During good weather conditions, the relation is the same for $\mathrm{PM}_{10}$ while for $\mathrm{PM}_{2.5}$, window opening increases $\mathrm{I} / \mathrm{O}$. The results obtained can be compared, e.g., with the work of Morawska et al. (2001) who studied the relationship between indoor/outdoor airborne particles in 16 residential houses located in a suburban area of Brisbane, Australia, by measuring the mass concentration of particles smaller than $2.5 \mu \mathrm{m}$, and revealed that while temporary values of the ratio varied in a broad range from 0.2 to 2.5 for both lower and higher ventilation conditions, average values of the ratios were in the range from 1.01 to 1.08 , i.e., much higher than in Kraków. Many other studies have quantified the indoor/outdoor $\mathrm{PM}_{2.5}$ ratio and demonstrated that there is substantial between- and within-home variability of that index, illustrating the difficulty in utilizing the values to estimate contributions of ambient $\mathrm{PM}_{2.5}$ to cumulative indoor intake (e.g., Blondeau et al. 2005; Cao et al. 2005; Chen and Zhao 2011; MacNeill et al. 2012, 2014).

Following the pattern proposed by Hänninen et al. (2011), regression analysis was applied to the indoor and outdoor concentrations of $\mathrm{PM}_{10}$ and $\mathrm{PM}_{2.5}$. In the regression model, the slope can be interpreted as the mean infiltration factor across the days and measurements included, and the intercept as the corresponding mean level of indoor generated particles. As shown in Figs. 5 and 6, there are well visible differences between the days with good weather conditions (Fig. 5) and those with poor conditions (Fig. 6). Following the concept of Hänninen et al. (2011), the constant terms approximate the mean indoor source concentrations and these estimates are relatively more sensitive to outliers than the slopes estimating infiltration factors. In Kraków, the constant terms vary for $\mathrm{PM}_{2.5}$ from about $3 \mathrm{\mu g} \mathrm{m}^{-3}$ during good weather conditions to about 16 $18 \mu \mathrm{g} \mathrm{m}^{-3}$ during poor conditions, while for $\mathrm{PM}_{10}$ the corresponding values are much higher, 0.3-6 and 14$28 \mu \mathrm{g} \mathrm{m}^{-3}$. In case of $\mathrm{PM}_{2.5}$, the values are very similar for days with windows kept open or closed, while for $\mathrm{PM}_{10}$ they are much higher for days with windows kept closed. The coefficient of determination $\left(R^{2}\right)$ is much larger for days with good weather conditions (40-85\%) than for those with poor conditions (14-56\%), and in both groups larger values are observed for days with windows kept open. Those results suggest that weather conditions are a factor with a significant impact on indoor PM concentration but they also suggest that indoor emissions of PM deliver a large share of the total indoor PM volume. However, the latter conclusion should be interpreted with caution due to the impact of outlier values shown in Figs. 5 and 6. 
Fig. 5 Regression analyses for indoor and outdoor PM2.5 (a) and PM10 (b) concentrations, for cases with windows kept open or closed, during good weather conditions
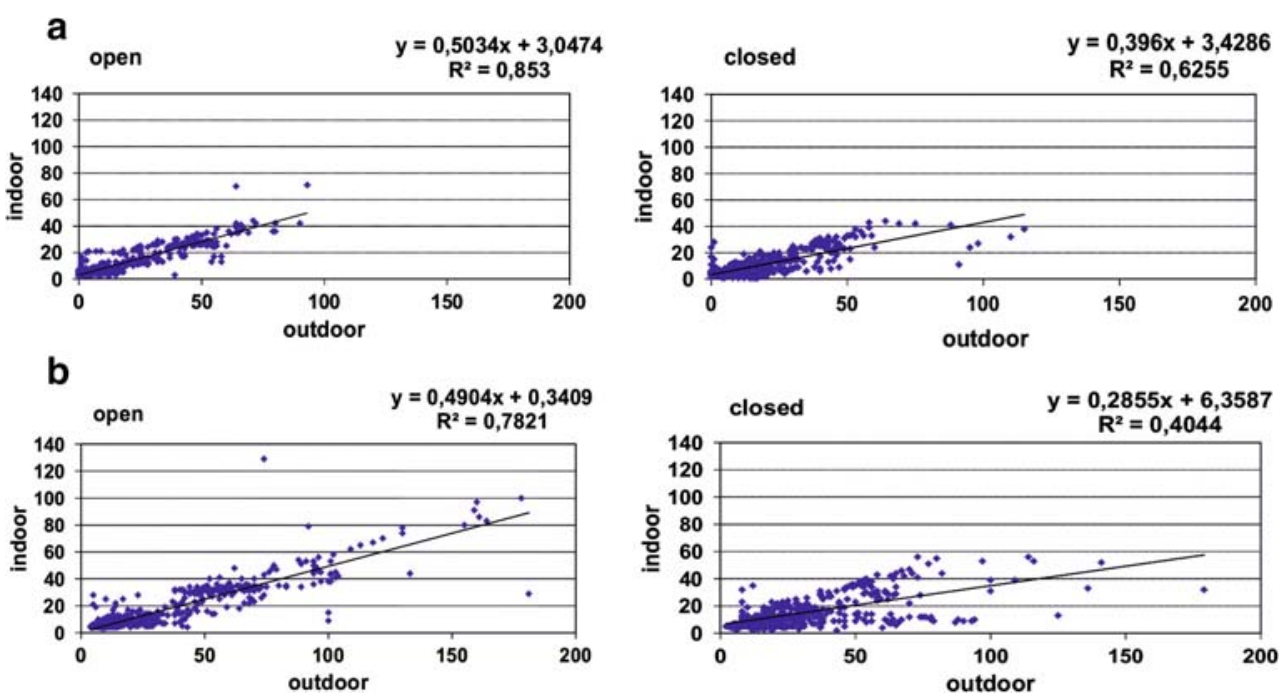

\section{Discussion and conclusion}

The maximum mean daily $\mathrm{PM}_{2.5}$ outdoor concentrations reached $115 \mu \mathrm{g} \mathrm{m}^{-3}$ for good weather conditions and $329 \mu \mathrm{g} \mathrm{m}^{-3}$ for poor conditions. For indoor concentrations, the values were 71 and $118 \mu \mathrm{g} \mathrm{m}^{-3}$, respectively. Those values are much higher than those reported for other cities, which also means a potentially higher environmental health risk. For example, according to Buczyńska et al. (2014), in Broechem near Antwerp (Belgium), maximum PM $_{2.5}$ concentrations reached $101 \mathrm{\mu g} \mathrm{m}^{-3}$ outdoors and $53.5 \mu \mathrm{g} \mathrm{m}^{-3}$ indoors, and the values were considerably higher than any of those measured during five other campaigns in Belgium between the years 2007 and 2010. In Birmingham, $7.9 \mu \mathrm{g} \mathrm{m}^{-3}$ was reported for residential indoor $\mathrm{PM}_{2.5}$ (Jones et al. 2000), and $9.1 \mu \mathrm{g} \mathrm{m}^{-3}$ in Oxford, England (Lai et al. 2004). A maximum of $56 \mu \mathrm{g} \mathrm{m}^{-3}$ was observed for outdoor $\mathrm{PM}_{2.5}$ in
Canada (Cheng et al. 1998), and $66 \mu \mathrm{g} \mathrm{m} \mathrm{m}^{-3}$ (PM2.5 $12 \mathrm{~h}$ day sample) in a study of air quality in offices near a busy street in the center of Antwerp (Horemans and Van Grieken 2010). However, much higher concentrations can be found elsewhere, especially in Asia, for example, Ye et al. (2003), in a yearly study in Shanghai, reported weekly averages of $\mathrm{PM}_{2.5}$ equal to $156 \mu \mathrm{g} \mathrm{m}^{-3}$.

Pekey et al. (2010) summarized various studies concerning mean seasonal $\mathrm{PM}_{2.5}$ and $\mathrm{PM}_{10}$ mass concentrations $\left(\mu \mathrm{g} \mathrm{m}^{-3}\right)$, completed in various countries. For the winter season, indoor concentrations for $\mathrm{PM}_{2.5}$ varied from 7.29 (Washington, USA) to 109.9 (Guangzhou, China), for $\mathrm{PM}_{10}$ it was from 11.93 (Washington, USA) to 103.8 (Santiago, Chile), and for outdoor conditions the values were for $\mathrm{PM}_{2.5}$ from 10.47 (Washington, USA) to 123.7 (Guangzhou, China), while for $\mathrm{PM}_{10}$ from 13.47 (Washington, USA) to 115.5 (Santiago, Chile). For Kraków, mean seasonal values, i.e.,
Fig. 6 Regression analyses for indoor and outdoor PM2.5 (a) and PM10 (b) concentrations, for cases with windows kept open or closed, during poor weather conditions
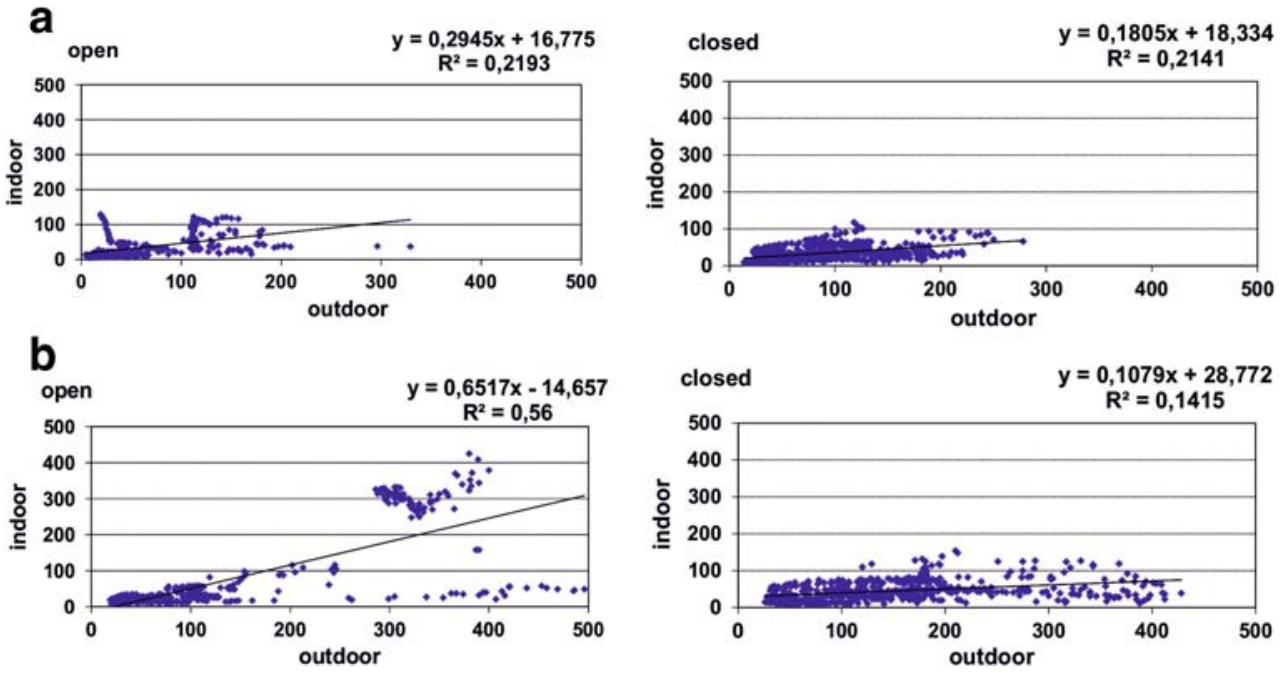
average values for all 98 days in the cold half-year when the measurements were conducted, were $24.2,36.2,49.6$, and $89.2 \mu \mathrm{g} \mathrm{m}^{-3}$, respectively, which means that air pollution with $\mathrm{PM}_{2.5}$ and $\mathrm{PM}_{10}$ was relatively high in comparison to other cities; indoor values were close to the allowed thresholds, but outdoor values exceeded them largely.

The data sets analyzed represent two opposite types of weather situations when indoor and outdoor $\mathrm{PM}_{2.5}$ and $\mathrm{PM}_{10}$ concentrations differ significantly. The results obtained can be compared to the outcomes of other studies. For example, Koponen et al. (2001) and Hodas et al. (2016) stated that outdoor-generated $\mathrm{PM}_{2.5}$ which penetrates into and persists in the indoor environment is a major source of indoor $\mathrm{PM}_{2.5}$. According to the results obtained for Kraków, indoor $\mathrm{PM}_{2.5}$ concentrations are much higher during poor weather conditions than during good ones (Fig. 2), and during poor weather conditions, window opening worsens the situation further; that is also the case during good weather conditions (Fig. 4).

The I/O ratios reported in various studies differ a lot and are governed by many factors. For example, Blondeau et al. (2005) found them to be greater than 1 and to strongly depend on particle size: $\mathrm{I} / \mathrm{O}$ ratios are higher, the larger the particles in optical diameter. In the case of Kraków, no such relationship can be observed (Fig. 4). However, Blondeau et al. (2005) stated that the phenomenon mainly originates from higher deposition rates of large particles on indoor surfaces rather than higher filtering efficiencies of the building envelopes. Still, the measurements provide no way to discriminate between the contribution of the two phenomena, and the question of how particle size influences their transport through the building envelope remains open. Cao et al. (2005) studied the I/O ratios of $24 \mathrm{~h} \mathrm{PM}_{2.5}$ concentrations in roadside, urban, and rural environments. The values obtained had a fairly narrow range (i.e., from 0.8 to $1.4,1.2$ to 2.0 , and 1.0 to 1.8 , respectively), averaging approximately 1.0 at roadside and rural sites and 1.5 at urban sites, and higher $\mathrm{I} / \mathrm{O}$ ratios at the urban sites indicated that they were affected by indoor pollutant sources. The results for Kraków show the I/O values were well below 1 (Fig. 4) but the fact that indoor concentrations are much lower than outdoor ones should be confronted with much higher outdoor and indoor PM concentrations in Kraków than in many other cities, as described above. It can then be assumed that indoor emissions, which are probably of comparable volume in Kraków and other European cities, have much lower significance in the total indoor PM concentration than in other cities, due to much larger amounts of PM migrating inside the buildings. Cao et al. (2005) also studied correlations between the indoor and outdoor $\mathrm{PM}_{2.5}$ measurements as they also imply the degree to which outdoor $\mathrm{PM}_{25}$ contributes to indoors. The correlations obtained were 0.24 for roadside, 0.72 for urban, and 0.98 for rural microenvironments. In case of Kraków, the values for good weather conditions were much higher (0.92 for cases with windows kept open and 0.79 for windows kept closed) than for poor weather conditions ( 0.46 and 0.47 , respectively) which is in accordance with the regression analysis results presented above.

The main aim of the present paper is the analysis of the significance of weather conditions in controlling the indoor PM concentrations. Taking under consideration the results presented above, it can be concluded that:

1. In Kraków, a medium-sized city in Central Europe, located in a concave land form, in a cold half-year, on days with poor weather conditions, the PM concentrations are 3 to 4 times higher than during good conditions.

2. Keeping the windows open or closed has no statistically significant impact on indoor $\mathrm{PM}_{2.5}$ concentration, regardless the weather type but in the case of $\mathrm{PM}_{10}$, window opening significantly increases indoor concentrations in both the weather types.

3. The share of $\mathrm{PM}_{2.5}$ in $\mathrm{PM}_{10}$ indoor and outdoor concentrations is significantly higher during poor weather conditions than during good ones by about $10 \%$. Window opening has no significant impact in both the weather types.

4. Mean $\mathrm{I} / \mathrm{O}$ values for $\mathrm{PM}_{10}$ and $\mathrm{PM}_{2.5}$ are higher when windows are closed than when they are opened, during poor weather conditions. During good weather conditions, the relation is the same for $\mathrm{PM}_{10}$ while for $\mathrm{PM}_{2.5}$, window opening increases I/O.

5. During good weather conditions and for apartments where the windows were kept open, PM indoor concentrations show a much larger dependence on outdoor concentrations than during poor weather conditions in apartments where the windows were kept closed.

In summary, this allows the conclusion that weather conditions are a factor with a significant impact not only on outdoor but also on indoor PM concentrations. In some cases, keeping the windows closed is not an efficient method of protection of the apartments from smog conditions observed outdoors, especially concerning $\mathrm{PM}_{2.5}$, which is more harmful for human health.

Acknowledgments This work was partially supported by the National Science Centre, Poland, project No. DEC-2011/03/B/NZ7/00644. The research protocol was approved by the Jagiellonian University Bioethics Committee. The authors wish to thank Mr. Pawel Chrustek for the assistance in preparation of Fig. 1.

\section{Compliance with ethical standards}

Conflict of interests The authors declare that they have no conflict of interests. 
Open Access This article is licensed under a Creative Commons Attribution 4.0 International License, which permits use, sharing, adaptation, distribution and reproduction in any medium or format, as long as you give appropriate credit to the original author(s) and the source, provide a link to the Creative Commons licence, and indicate if changes were made. The images or other third party material in this article are included in the article's Creative Commons licence, unless indicated otherwise in a credit line to the material. If material is not included in the article's Creative Commons licence and your intended use is not permitted by statutory regulation or exceeds the permitted use, you will need to obtain permission directly from the copyright holder. To view a copy of this licence, visit http://creativecommons.org/licenses/by/4.0/

\section{References}

Almeida-Silva M, Wolterbeek HT, Almeida SM (2014) Elderly exposure to indoor air pollutants. Atmos Environ 85:54-63. https://doi.org/ 10.1016/j.atmosenv.2013.11.061

Blondeau P, Iordache V, Poupard O, Genin D, Allard F (2005) Relationship between outdoor and indoor air quality in eight French schools. Indoor Air 15:2-12. https://doi.org/10.1111/j. 1600-0668.2004.00263.x

Bokwa A (2008) Environmental impacts of long-term air pollution changes in Kraków, Poland. Pol J Environ Stud 17:673-686 http:// www.pjoes.com/Environmental-Impacts-of-Long-Term-Air-rnPollution-Changes-in-Krakow-Poland,88153,0,2.html. Accessed 1 December 2019

Bokwa A (2010) Wieloletnie zmiany struktury mezoklimatu miasta na przykładzie Krakowa [Multi-annual changes of the urban mesoclimate structure (using an example of Kraków)]. Institute of Geography and Spatial Management, Jagiellonian University, Kraków, p 258 http://www.geo.uj.edu.pl/publikacje.php?\&lang= $1 \&$ page $=$ monografie $\&$ menu $=3 \& i d=000155$. Accessed 1 December 2019

Bokwa A (2011) Influence of air temperature inversions on the air pollution dispersion conditions in Krakow. Pr Geogr IGiGP UJ 126:4151 http://www.pg.geo.uj.edu.pl/documents/3189230/4482219/ 2011 126_41-51.pdf/3a9b98f7-8324-48de-a772-aba57ac3aae2. Accessed 1 December 2019

Buczyńska AJ, Krata A, Van Grieken R, Brown A, Polezer G, DeWael K, Potgieter-Vermaak S (2014) Composition of PM2.5 and PM1 on high and low pollution event days and its relation to indoor air quality in a home for the elderly. Sci Total Environ 490:134-143. https://doi.org/10.1016/j.scitotenv.2014.04.102

Cao JJ, Lee SC, Chow JC, Cheng Y, Ho KF, Fung K, Liu SX, Watson JG (2005) Indoor/outdoor relationships for PM2.5 and associated carbonaceous pollutants at residential homes in Hong Kong-case study. Indoor Air 15:197-204. https://doi.org/10.1111/j.1600-0668. 2005.00336.x

Chao CY, Wong KK (2002) Residential indoor PM10 and PM2.5 in Hong Kong and the elemental composition. Atmos Environ 36: 265-277. https://doi.org/10.1016/S1352-2310(01)00411-3

Chen C, Zhao B (2011) Review of relationship between indoor and outdoor particles: I/O ratio, infiltration factor and penetration factor. Atmos Environ 45:275-288. https://doi.org/10.1016/j.atmosenv. 2010.09 .048

Cheng L, Sandhu HS, Angle RP, Myrick RH (1998) Characteristics of inhalable particulate matter in Alberta cities. Atmos Environ 32: 3835-3844. https://doi.org/10.1016/S1352-2310(98)00046-6

Clayton C, Perritt R, Pellizzari E, Thomas K, Whitmore R, Wallace L, Ozkaynak H, Spengler J (1993) Particle total exposure assessment methodology (PTEAM) study: distributions of aerosol and elemental concentrations in personal, indoor, and outdoor air samples in a southern California community. J Expo Anal Environ Epidemiol 3:227-250

Deng X, Cao W, Huo Y, Yang G, Yu C, He D, Deng W, Fu W, Ding H, Zhai J, Cheng L, Zhao X (2019) Meteorological conditions during a severe, prolonged regional heavy air pollution episode in eastern China from December 2016 to January 2017. Theor Appl Climatol 135:1105-1122. https://doi.org/10.1007/s00704-018-2426-4

European Environment Agency (2018) Air quality in Europe-2018 report. European Environment Agency, Luxembourg, Publications Office of the European Union. http://www.eea.europa.eu. Accessed 15 November 2019

Gemenetzis P, Moussas P, Arditsoglou A, Samara C (2006) Mass concentration and elemental composition of indoor PM2.5 and PM10 in university rooms in Thessaloniki, northern Greece. Atmos Environ 40:3195-3206. https://doi.org/10.1016/j.atmosenv.2006.01.049

Hajto M, Rozwoda W (2010) Wykorzystanie danych sodarowych do oceny warunków rozprzestrzeniania się zanieczyszczeń w warstwie granicznej atmosfery w Krakowie [Application of sodar data to evaluate the conditions of the air pollution dispersion in the boundary layer in Kraków]. In: Konieczyński J (ed) Ochrona powietrza w teorii i praktyce [Atmosphere protection in theory and practice], vol 2. Institute of Environmental Engineering, Polish Academy of Sciences, Zabrze, pp 81-92

Hänninen O, Hoek G, Mallone S, Chellini E, Katsouyanni K, Gariazzo C, Cattani G, Marconi A, Molnar P, Bellander T, Jantunen M (2011) Seasonal patterns of outdoor PM infiltration into indoor environments: review and meta-analysis of available studies from different climatological zones in Europe. Air Qual Atmos Health 4:221-233. https://doi.org/10.1007/s11869-010-0076-5

Hodas N, Loh M, Shin H-M, Li D, Bennett D, McKone TE, Jolliet O, Weschler CJ, Jantunen M, Lioy P, Fantke P (2016) Indoor inhalation intake fractions of fine particulate matter: review of influencing factors. Indoor Air 26:836-856. https://doi.org/10.1111/ina. 12268

Horemans B, Van Grieken R (2010) Speciation and diurnal variation of thoracic, fine thoracic and sub-micrometer airborne particulate matter at naturally ventilated office environments. Atmos Environ 44: 1497-1505. https://doi.org/10.1016/j.atmosenv.2010.01.010

Hu R, Wang S, Aunan K, Zhao M, Chen L, Liu Z, Hansen Mette H (2019) Personal exposure to PM2.5 in Chinese rural households in the Yangtze River Delta. Indoor Air 29:403-412. https://doi.org/10. 1111/ina. 12537

Ilacqua V, Hanninen O, Kuenzli N, Jantunen MF (2007) IF distributions for indoor VOC sources in five European cities. Indoor Air 17:372383. https://doi.org/10.1111/j.1600-0668.2007.00485.x

Inspectorate of Environmental Protection (2019) System monitoringu jakości powietrza [Air quality monitoring system]. http:// monitoring.krakow.pios.gov.pl/. Accessed 15 November 2019

Isaxon C, Gudmundsson A, Nordin EZ, Lonnblad L, Dahl A, Wieslander G, Bohgard M, Wierzbicka A (2015) Contribution of indoorgenerated particles to residential exposure. Atmos Environ 106: 458-466. https://doi.org/10.1016/j.atmosenv.2014.07.053

Jones NC, Thornton CA, Mark D, Harrison RM (2000) Indoor/outdoor relationship of particulate matter in domestic homes with roadside, urban and rural locations. Atmos Environ 34:2603-2612. https:// doi.org/10.1016/S1352-2310(99)00489-6

Klaić ZB, Ollier SJ, Babić K, Bešlić I (2015) Influences of outdoor meteorological conditions on indoor wintertime short-term PM1 levels. Geofizika 32(2):237-264. https://doi.org/10.15233/gfz.2015.32.12

Klepeis NE, Nazaroff WW (2006) Modeling residential exposure to secondhand tobacco smoke. Atmos Environ 40:4393-4407. https://doi. org/10.1016/j.atmosenv.2006.03.018

Koponen IK, Asmi A, Keronen P, Putho K, Kulmala M (2001) Indoor air measurement campaign in Helsinky, Finland, 1999 - the effect of outdoor air pollution on indoor air. Atmos Environ 35:1465-1477. https://doi.org/10.1016/S1352-2310(00)00338-1 
Lai HK, Kendall M, Ferrier H, Lindup I, Alm S, Hänninen O (2004) Personal exposures and microenvironment concentrations of PM2.5, VOC, NO2, CO in Oxford, UK. Atmos Environ 38:63996410. https://doi.org/10.1016/j.atmosenv.2004.07.013

Lewińska J, Bartosik J, Baścik J, Czerwieniec M, Zgud K (1982) Wpływ miasta na klimat lokalny (na przykładzie aglomeracji krakowskiej) [Impact of a city on local climate (with Kraków agglomeration as an example)]. Institute of Environmental Management, Warsaw

Li Y, Chen Q, Zhao H, Wang L, Tao R (2015) Variations in PM10, PM2.5 and PM1.0 in an urban area of the Sichuan Basin and their relation to meteorological factors. Atmosphere 6:150-163. https://doi.org/10. 3390/atmos6010150

MacNeill M, Wallace L, Kearney J, Allen RW, Van Ryswyk K, Judek S, $\mathrm{Xu} \mathrm{X,} \mathrm{Wheeler} \mathrm{A} \mathrm{(2012)} \mathrm{Factors} \mathrm{influencing} \mathrm{variability} \mathrm{in} \mathrm{the} \mathrm{infil-}$ tration of PM2.5 mass and its components. Atmos Environ 61:518532. https://doi.org/10.1016/j.atmosenv.2012.07.005

MacNeill M, Kearney J, Wallace L, Gibson M, Heroux ME, Kuchta J, Guernsey JR, Wheeler AJ (2014) Quantifying the contribution of ambient and indoor-generated fine particles to indoor air in residential environments. Indoor Air 24:362-375. https://doi.org/10.1111/ ina. 12084

Morawska L, He C, Hitchins J, Gilbert D, Parappukkaran S (2001) The relationship between indoor and outdoor airborne particles in the residential environment. Atmos Environ 35:3463-3473. https:// doi.org/10.1016/S1352-2310(01)00097-8

Niedźwiedź T (2019) Catalogue of synoptic situations in the upper Vistula river basin (1873.09-2015.12). Computer file available at: Department of Climatology, Faculty of Earth Sciences, University of Silesia, Będzińska 60, 41-200 Sosnowiec, Poland; http://klimat. wnoz.us.edu.pl. Accessed 20 June 2019

Niedźwiedź T, Olecki Z (1994) Wpływ sytuacji synoptycznych na zanieczyszczenie powietrza w Krakowie [Impact of synoptic situations on air pollution in Krakow]. Zesz Nauk UJ, Pr Geogr 96:55-68

Niedźwiedź T, Olecki Z (1995) The variability of air pollution in Cracow. In: Kłysik K (ed) Klimat i bioklimat miast [Climate and bioclimate of cities]. Publishing House of Łódź University, Łódź, pp 205-212

Oke TR (1987) Boundary layer climates. Methuen, London

Paoin K, Ueda K, Seposo XT, Hayano J, Kiyono K, Ueda N, Kawamura T, Honda A, Takano H (2020) Association between PM2.5 exposure and heart rate variability for the patients with cardiac problems in Japan. Air Qual Atmos Health 13:339-347. https://doi.org/10.1007/ s11869-020-00797-8

Pekey B, Bozkurt ZB, Pekey H, Dogan G, Zararsız A, Efe N, Tuncel G (2010) Indoor/outdoor concentrations and elemental composition of PM10/PM2.5 in urban/industrial areas of Kocaeli City, Turkey. Indoor Air 20:112-125. https://doi.org/10.1111/j.1600-0668.2009. 00628.x

Pope CA, Dockery DW (2006) Health effects of fine particulate air pollution: lines that connect. J Air Waste Manag Assoc 56:709-742. https://doi.org/10.1080/10473289.2006.10464485

Prtenjak MT, Jericevic A, Kraljevic L, Bulic IH, Nitis T, Klaic ZB (2009) Exploring atmospheric boundary layer characteristics in a severe $\mathrm{SO}_{2}$ episode in the north-eastern Adriatic. Atmos Chem Phys 9: 4467-4483. https://doi.org/10.5194/acp-9-4467-2009

Rojas-Bracho L, Suh H, Koutrakis P (2000) Relationships among personal, indoor, and outdoor fine and coarse particle concentrations for individuals with COPD. J Expo Sci Environ Epidemiol 10:294-306. https://doi.org/10.1038/sj.jea.7500092

Ścibor M, Galbarczyk A, Jasienska G (2019a) Living well with pollution? The impact of the concentration of PM2.5 on the quality of life of patients with asthma. Int J Environ Res Public Health 14:2502. https://doi.org/10.3390/ijerph16142502

Ścibor M, Balcerzak B, Galbarczyk A, Targosz N, Jasienska G (2019b) Are we safe inside? Indoor air quality in relation to outdoor concentration of PM10 and PM2.5 and to characteristics of homes. Sustain Cities Soc 48:101537. https://doi.org/10.1016/j.scs.2019. 101537

Seinfeld JH, Pandis SN (1998) Atmospheric chemistry and physics: from air pollution to climate change. Wiley, New York

Shi S, Chen C, Zhao B (2017) Modifications of exposure to ambient particulate matter: tackling bias in using ambient concentration as surrogate with particle infiltration factor and ambient exposure factor. Environ Pollut 220:337-347. https://doi.org/10.1016/j.envpol. 2016.09.069

Statistical Yearbook of Kraków (2017) https://krakow.stat.gov.pl. Accessed 15 November 2019

Statistical Yearbook of Kraków (2019) https://krakow.stat.gov.pl. Accessed 15 February 2020

Taneepanichskul N, Gelaye B, Grigsby-Toussaint DS, Lohsoonthorn V, Jimba M, Williams MA (2018) Short-term effects of particulate matter exposure on daily mortality in Thailand: a case-crossover study. Air Qual Atmos Health 11(6):639-647. https://doi.org/10. 1007/s11869-018-0571-7

Toro R, Kvakić M, Klaić ZB, Koračin D, Morales RGE, Leiva MA (2019) Exploring atmospheric stagnation during a severe particulate matter air pollution episode over complex terrain in Santiago, Chile. Environ Pollut 244:705-714. https://doi.org/10.1016/j.envpol.2018. 10.067

Vecchi R, Marcazzan G, Valli G, Ceriani M, Antoniazzi C (2004) The role of atmospheric dispersion in the seasonal variation of PM1 and PM2.5 concentration and composition in the urban area of Milan (Italy). Atmos Environ 38:4437-4446. https://doi.org/10.1016/j. atmosenv.2004.05.029

Walczewski J, Feleksy-Bielak M, Dębicka K, Śliwińska U (2000) Wskaźniki meteorologicznych warunków dyspersji zanieczyszczeń powietrza i ich zmienność w Krakowie w latach 1990-1999 [Indices of meteorological conditions of air pollution dispersion and their variability in Kraków in the years 1990-1999]. Wiad IMGW 23(3):13-27

Wallace LA (1996) Indoor particles: a review. J Air Waste Manage Assoc 46:98-126

Wallace LA (2000) Correlations of personal exposure to particles with outdoor air measurements: a review of recent studies. Aerosol Sci Technol 32:15-25. https://doi.org/10.1080/027868200303894

Williams R, Suggs J, Rea A, Sheldon L, Rodes C, Thornburg J (2003) The research triangle park particulate matter panel study: modeling ambient source contribution to personal and residential PM mass concentrations. Atmos Environ 37:5365-5378. https://doi.org/10. 1016/j.atmosenv.2003.09.010

World Health Organization (2013) Review of evidence on health aspects of air pollution-REVIHAAP project: technical report. WHO, Geneva http://www.euro.who.int/en/health-topics/environmentand-health/air-quality/publications/2013/review-of-evidence-onhealth-aspects-of-air-pollution-revihaap-project-final-technicalreport. Accessed 1 December 2019

Yang J, Shi B, Shi Y, Marvin S, Zheng Y, Xia G (2020) Air pollution dispersal in high density urban areas: research on the triadic relation of wind, air pollution, and urban form. Sustain Cities Soc 54: 101941. https://doi.org/10.1016/j.scs.2019.101941

Ye B, Ji X, Yang H, Yao X, Chan CK, Cadle S (2003) Concentration and chemical composition of PM2.5 in Shanghai for a 1-year period. Atmos Environ 37:499-510. https://doi.org/10.1016/S13522310(02)00918-4

Publisher's note Springer Nature remains neutral with regard to jurisdictional claims in published maps and institutional affiliations. 